\title{
The Effect of Periodization Based on Mind Mapping Learning Model on Students' Understanding in Social Studies in Primary School
}

\author{
Itsna Oktaviyanti* \\ Primary Teacher Education Program \\ Universitas Mataram \\ Mataram Indonesia \\ itsna@unram.ac.id \\ Nurhasanah Nurhasanah \\ Primary Teacher Education Program \\ Universitas Mataram \\ Mataram Indonesia
}

\author{
Ilham Syahrul Jiwandono \\ Primary Teacher Education Program \\ Universitas Mataram \\ Mataram Indonesia \\ Awal Nur Kholifatur Rosyidah \\ Primary Teacher Education Program \\ Universitas Mataram \\ Mataram Indonesia
}

\begin{abstract}
This study aims to determine the effect of the Mind Mapping-based model on students' understanding in social studies in primary school. The study was conducted using quasi experimental design. The populations were the second semester students of Primary School Education Program, Universitas Mataram. The simple random sampling technique was used and the sample consisted of 2D class as the experimental class and the $2 \mathrm{C}$ as the control class. The experimental class was treated with the learning using Mind Mapping model based on periodization, while the control class carried out learning using the Mind Mapping model. Data analysis technique used the Lilliefors test to test data normality, Levene test for homogeneity test and Mann-Whitney U test with $5 \%$ significance for testing the hypothesis. The results of the Mann-Whitney $U$ test showed a significant value of 0.047 , lower than 0.05 , which means that the hypothesis was rejected. It is concluded that Mind Mapping model based on periodization affected, even though not so significantly, the students' understanding in social studies in primary school.
\end{abstract}

Keywords - mind mapping-based on periodization, students' understanding, social studies

\section{INTRODUCTION}

A teacher is a professional educator with his/or her primary roles in educating, teaching, guiding, directing, training, and evaluating students in the early childhood education through formal education, basic education and secondary education. The Law No. 142005 states that there are four competencies that must be possessed by a teacher, namely, pedagogical, social, personality and professional competencies. Not only teachers, prospective teachers must comprehend these four competencies, so that later they can apply in the teaching and learning process. Professional competence is the ability of teachers to master broad and indepth subject matter that allows them to guide the students to meet the competencies set out in the National Education Standards. At the elementary school level, classroom teachers are required to master 5 fields of study, one of which is social study.

Social study is a subject studying human and the world around them. The materials in social studies in elementary schools focus very much on the fields of Economics,
Geography and History. The history which is taught at the elementary level is the Indonesian history before and after independence. The broad and complex scope of material is one of the reasons why social study is considered as a difficult subject to understand.

The students of Primary School Education Program as future elementary school teachers are required to understand all social studies material taught in elementary schools. Students in this program are the future intermediaries in transferring knowledge to their students later so that they not only have the ability to remember but also to understand. However, through the interview process conducted to the Primary School Education Program students, most of them only remember the material without understanding it. The lack of students' understanding is reflected in some of the questions given about social studies material, most students find it difficult to answer. The difficulties experienced due to the questions given are not the same with the memory that has been embedded they only know the outline of each material without comprehending the whole materials. Hence, they not only have the ability to remember but also the ability to understand.

Problems occur in PSEP students must be given a special attention, students as future teachers must master the materials so that later they can carry out the teaching process properly. As quoted from the results of Novauli's study [1] that teacher will not be able to explain the subject matter properly if they do not master the explained material.

Things that must be considered to solve this problem are the use of learning models or methods that can build students' understanding on social matter. There are many interesting learning models and predicted to be effective in helping students understanding the social studies, one of which is the cooperative model. Cooperative learning models emphasize more cooperation and increase the activity of students so that they will be easy to understand the concept in a fun way [2]. One of the models included in cooperative learning that is appropriate to facilitate students in understanding the concept of social studies material in 
primary schools is the mind mapping based on periodization which is a modification of mind mapping learning model.

Buzan explained that "Mind mapping is an application that gives us meaningful information to understand in a simple way. Mind Mapping Technique prepares the mind in a way that information can be used in logical and imaginary ways to make an image in the brain. In Mind Mapping Technique, the first main idea is specified and then the linear view is explained. It is also useful for self and group in which it can have more effects than written reviews. This method is suitable for teachers and students for the recurrence and easy to understand hard topics [3]. The simple method in question is neither complicated nor monotonous by including colors and drawings in notes that match the material. This is in line with the result of research from Syam and Ramlah [4] which explains that one of the factors causing low learning outcomes was that students only made monotonous notes.

Mind mapping based on periodization is a learning model that is organized according to the period in which it occurs and will display events that occur first to a period that is closer to the present. By using this model, students are expected to understand social studies material about events before and after independence as preparation for being professional teachers. This modification is the same as the development of mind mapping model which is expected to have a good impact on students. Developing mind mapping needed to make it easier for students to learn social studies in fun way which is very relevant for elementary students. The lessons are packaged by using a variety of images, colors, and students themselves who directly make students better understand the subject matter delivered [5]. Therefore, the present study was conducted under the title the Effect of Periodization Based on Mind Mapping Learning Model on Students' Understanding Social Studies in Primary School.

\section{METHOD}

This is an experimental study with quasi experimental design. The quasi experimental design used is the nonequivalent control group design. There are two groups in this study, experimental and control group, in which students were given pre- and post-test to find out whether there are difference between the experimental group and the control group.

The population in this study was the second semester students of primary school education study program. The population consists of four classes - 2A, 2B, 2C and 2D with 155 students. The technique of sampling used in this study is the simple random sampling. Simple random sampling is a selection method of population units where the units are all randomized, and it was carried out using a lottery. The result, the $2 \mathrm{C}$ and $2 \mathrm{D}$ as the research sample with 76 students, in which $2 \mathrm{D}$ became the experimental class and $2 \mathrm{C}$ became the control class. The experimental class carried out learning using the Mind Mapping model based on periodization, while the control class carried out learning using the Mind Mapping model. The comparison result of the two classes is to answer the influence of the Mind Mapping based on the Periodization model towards students' understanding on the elementary social studies material.
The data were collected in this research by using tests and documentation. The test was used to measure students' learning outcomes as part of a students' obligation to measure the success of the learning process. As stated by Iswanto and Roniwijaya [6], the main task of a student is learning, how much the activity of a student is generally measured in the form of the learning outcome. The test was used to determine students' understanding on social studies. The questions of the test were first tested to students outside the sample, which is $2 \mathrm{~A}$ class with 22 questions that were declared valid and reliable from 30 questions available. While, the documentation was used to find out the process of learning. The analysis technique used is the Lilliefors test to test data normality, the Levene test for homogeneity test and the Mann-Whitney U test with 5\% significance for the final hypothesis test.

\section{RESULTS AND DISCUSSION}

This study aims to determine the effect of the Mind Mapping based model on students' understanding of elementary social studies material. Data analysis used in this study includes the statistical analysis pretest results, statistical analysis of 2C and 2D students' understanding. Hypothesis was tested by comparing students' understanding of 2D students using Mind Mapping models based on the periodization to students' understanding with $2 \mathrm{C}$ students' understanding using the Mind Mapping model.

\section{A. Pretest Results}

A pretest was conducted to determine the initial state of each sample group. Pretest was done by conducting multiple choice tests on all sample groups. The pretest results for the 2D class obtained an average of 7.05 out of 20 questions worked on, while the pretest results for the $2 \mathrm{C}$ class obtained an average of 7.32 out of 20 questions worked out. The results of the pretest value from the initial ability of students in $2 \mathrm{D}$ and $2 \mathrm{C}$ classes on social study are relatively the same and not significantly different. It means that the two classes can be sampled in this experimental study.

\section{B. Results of the Experimental Posttest Class}

The experimental class in this study was the 2D class of Primary School Education Study Program, Universitas Mataram. Class 2D consisted of 40 students, but only 38 students attended during the data collection process, so the sample used in 2D class was 28 students.

The experimental class was treated using a Mind Mapping model based on periodization. The learning process began with a brief delivery of material and an explanation about the making of Mind Mapping based on Periodization. After students understood the explanation from the lecturer, students were assigned to make mind maps individually. Researchers made modifications in the steps of Mind Mapping learning in the grouping section because it was thought that students were autonomous to make themselves. Classification was carried out only for the process of discussion about the material and procedures for making Mind Mapping.

The Mind Mapping based on periodization model is actually not different in terms of its implementation. The process of making and writing material drawn in the form of a Mind Mapping was based on the period of occurrence of an 
event related to the given Social study for elementary school material. The elementary social studies material discussed in this study are events before and after independence. After finished making their Mind Mapping, students were asked to re-read the work they have made to study it well. Modifications of learning with mind mapping models aim to make the learning process more interesting and it can improve student' understanding. This is in line with the research conducted by Suherlin [7] which is based on an analysis of student responses to the learning process through the application of learning models.

Mind mapping with the image media varies largely. Although it varies, students' responses to all aspects were above $85 \%$. There are $90 \%$ of students felt the model was interesting, $100 \%$ of students agreed that the model was new, $86 \%$ of students felt the model helped to clarify students' understanding of the subject matter. The results of posttest analysis at the $2 \mathrm{D}$ class as an experimental class are as follows:

TABLE I. POSTTEST SCORE OF EXPERIMENT Class

\begin{tabular}{cccc}
\hline Score & Category & F & Percentage \\
\hline $16-$ & Very & 32 & $84.2 \%$ \\
20 & good & & \\
\hline $14-$ & Good & 2 & $5.3 \%$ \\
15 & & & \\
\hline $\begin{array}{c}12- \\
13\end{array}$ & Fairly & 1 & $2.6 \%$ \\
\hline$<12$ & Good & & \\
\hline
\end{tabular}

From Table 1, (1) the frequency of students who correctly answered 16-20 questions at the very good category are 32 students or $84.2 \%$, (2) the frequency of students who answered correctly 14-15 questions at the good category are 2 students or $5.3 \%$, (3) the frequency of students who answered correctly 12-13 questions with fairly good category is only 1 student or $2.6 \%$, (4) the frequency of students who answered correctly $<12$ questions with low category are 3 students or $7.9 \%$. Then, it shows that the average score of the experimental class students who answered correctly about the matter understanding in elementary social studies are 17.52 which included in the very good category.

\section{Results of Control Posttest Class}

The control class in this study was 2C class of Primary School Education program, Universitas Mataram. Class 2C consists of 39 active students, but during the data collection process, one student was absent due to illness so there are 38 totals of students used in the class. In contrast to the experimental class that received treatment in the form of Mind Mapping model based on the periodization, the control class received treatment in the form of using the Mind Mapping model. The results of the posttest analysis score in class $2 \mathrm{C}$, as a control class, are as follows:

TABLE II. POSTTEST SCORE OF CONTROL ClasS

\begin{tabular}{cccc}
\hline Score & Category & F & Percentage \\
\hline $16-20$ & $\begin{array}{c}\text { Very } \\
\text { good }\end{array}$ & 28 & $73.7 \%$ \\
\hline $14-15$ & Good & 3 & $7.9 \%$ \\
\hline $12-13$ & $\begin{array}{l}\text { Fairly } \\
\text { Good }\end{array}$ & 3 & $7.9 \%$ \\
\hline$<12$ & Low & 4 & $10.5 \%$ \\
\hline
\end{tabular}

From the table 2 above, it can be seen that (1) the frequency of students who correctly answered 16-20 questions in the very good category were 28 students or $73.7 \%$, (2) the frequency of students who answered correctly 14-15 questions in good category are 3 students or at $7.9 \%$, (3) the frequency of students who answered correctly 12-13 questions with fairly good category are 3 students or at $3.9 \%$, (4) the frequency of students who answered correctly $<12$ questions with low category are 4 students or at $10.5 \%$. It was found that the average score of the experimental class students who answered correct on the understanding of social studies is 16.34 , very good category.

These results reinforce the previous research conducted by Iswanto and Roniwijaya [6] that there was a significant enhancement in the learning outcome after the using the Mind Mapping model. The enhancement is categorized very good due to less students who did not reached the minimum completeness of $100 \%$. This means that most students have reached the minimum standard.

From the data, it was found that after the two classes were treated, both the $2 \mathrm{D}$ class as the experimental class and the $2 \mathrm{C}$ class as the control class had a very good understanding on social studies material about events before and after independent day of Indonesia. The experimental class obtained an average of 17.52 or if interpreted with grades the average test score of 2D class is 87.6. Meanwhile, the control class obtained an average of 16.34 or if interpreted with grades the average test score is 81.7 .

\section{Hypothesis Analysis}

This study used experimental research using two classes, namely experimental and control class. The hypothesis analysis in this study is to test the effect of Mind Mapping model based on the periodization on the students' understanding the elementary social studies materials. To find out this effect, a comparison was made between the experimental class that was treated with learning using the Mind Mapping model based on the Periodization and the control class that was treated with learning using the Mind Mapping model. After receiving different treatments, both classes answered test that had been tested for its validity. The test results are the answers of the existing hypotheses. If there is a significant difference between the test results in the experimental and the control class, it can be said that there is an effect of the use of the Mind Mapping model on students' understanding.

The analysis test conducted in this study is the Lilliefors test to test data normality, the Levene test for homogeneity test and the Mann-Whitney U test with 5\% significance for the final hypothesis test. Liliefors test results indicated that the significance value of the experimental class test results 0.00 and the significance value of the test results control class 0.01 . From these results, the comprehending tests from the two classes are not normally distributed. Levene test results indicated that the results of the tests of both classes are at a significance level of 0.496 greater than 0.05 which means that the test results of both classes are homogeneous. Levene test results showed that the results of the tests of both classes are at a significance level of 0.496 greater than 0.05 , this means that the test results of both classes are 
homogeneous. Final hypothesis testing used Mann-Whitney $\mathrm{U}$ with a significance level of $5 \%$ because the data from both classes are not normally distributed. Based on the analysis test conducted on the results of the two classes, it was found that the Mann-Whitney $U$ test results showed a significant value of 0.047 smaller than 0.05 , which means that there were significant differences between the test results of the experimental class and that of the control class. Thus, the hypothesis test conducted showed that the hypothesis is rejected. Based on these results, it can be concluded that Mind Mapping model based on periodization affected the students' understanding on social studies in Primary School.

Although the results of the analysis indicates that there is an effect of the Mind Mapping model on students' understanding of social studies material, the significance value is not too high, only 0.47 . In addition, the difference in the average value of the two classes is not too high, 17.52 for the experimental class and 16.34 for the control class. It means that the difference between the two is only 1.18 . Therefore, it is necessary to conduct a further study to support the findings of the present study.

This is not much different from the results of other studies which show that there is no significant difference in the understanding of student concepts in the use of mind mapping techniques with the use of conventional (narrative) learning journals. However, in terms of the average value, the understanding of the experimental class is greater than that of the control class. The use of mind mapping learning journals has a positive effect on the understanding concepts in the Professional Education course [8]. Similar to this research, although the difference was not too significant, it has shown that the use of Mind Mapping based on the Periodization Model has a positive effect on the PSEP students' understanding.

\section{CONCLUSION}

Based on the results of data analysis and discussion, it is found that the average test result of the experimental class is 17.53. This shows that the students' understanding in the experimental class is in the very good category. The average test result of the control class is 16.34. This shows that the students' understanding in the experimental class is in the very good category. The result of the Mann-Whitney U hypothesis test with 76 samples of students and a significant level of $5 \%$ obtained a significant value of less than 0.05 that is 0.047 . Based on the hypothesis test, it shows that there is a significant difference between the understanding of students who used the Mind Mapping model based on Periodization and the understanding of students who use the Mind Mapping model. Therefore, the hypothesis which states that there is no effect of the Mind Mapping based on the Periodization model on students' understanding on the Social Studies in Primary School material is rejected.

\section{REFERENCES} Prestasi Belajar pada SMP. Jurnal Administrasi Pendidikan , 3(1), 2015, 45-67.

[2] Latipah, Hani Wardah., dan Adman. Penerapan Model Pembelajaran Mind Mapping untuk Meningkatkan Hasil Belajar Peserta Didik. Jurnal Pendidikan Manajemen Perkantoran ,1(2), 2018, 125-137.
Parikh, Nikhilkumar D. 2016. Effectiveness of Teaching through Mind Mapping Technique. The International Journal of Indian Psychol. 3(3), 3, 2016, 148-156.

Syam, Natriani dan Ramlah. Penerapan Model Pembelajaran Mind Mapping Dalam Meningkatkan Hasil Belajar pada Mata Pelajaran Ilmu Pengetahuan Sosial Siswa Kelas IV SDN 54 Kota Pare Pare. Jurnal Publikasi Pendidikan. 5(3), 2015, 184197.

Darmayoga, I Wayan; I Wayan Lasmawan dan A.A.I.N Marhaeni. 2013. Pengaruh Implementasi Metode Mind Mapping Terhadap Hasil Belajar IPS Ditinjau Dari Minat Siswa Kelas IV SD Sathya Sai Denpasar. e-Journal Program Pascasarjana Universitas Pendidikan Ganesha Jurusan Pendidikan Dasar, Vol 3. 2013.

Iswanto, dan Pairun Roniwijaya. 2017. Pembelajaran Model Mind Map Untuk Meningkatkan Aktivitas Dan Hasil Belajar Kompetensi Sistem Kelistrikan Dan Instrumen Siswa Kelas Xi Teknik Sepeda Motor Smk Diponegoro Depok Sleman. Jurnal Taman Vokasi, 5(1), 2017, 92-105.

Suherlin, Syamsul Bardi dan Alamsyah Taher. 2017. Penerapan Model Pembelajaran Mind Mapping Berbantuan Media Gambar Pada Mata Pelajaran IPS Terpadu Untuk Meningkatkanhasil Belajar Siswa Kelas VIII SMP Negeri 1 Darussalam. Jurnal Ilmiah Mahasiswa Pendidikan Geografi FKIP Unsyiah, 2(3), 2017, 122-131.

Suciati, dan Chrisnia Octovi. Perbedaan Pengaruh Penggunaan Jurnal Belajar Mind Mapping (JBMM) dan Jurnal Belajar Naratif terhadap Pemahaman Konsep Mahasiswa Calon Guru Biologi pada Mata Kuliah Profesi Kependidikan. Proceeding Biology Education Conference, 13(1), 2016, 570-574. 